\title{
Recent developments in cattle, pig, sheep and horse breeding - a review
}

\author{
Alena Svitáková ${ }^{1,2}$, Jitka Schmidová $^{1,2}$, Petr Pešek ${ }^{1}$, Alexandra Novotná $^{1}$ \\ ${ }^{1}$ Institute of Animal Science, Prague - Uhř́něves, Czech Republic \\ ${ }^{2}$ Czech University of Life Sciences Prague, Prague - Suchdol, Czech Republic
}

Received June 30, 2014

Accepted September 17, 2014

\begin{abstract}
The aim of this review was to summarize new genetic approaches and techniques in the breeding of cattle, pigs, sheep and horses. Often production and reproductive traits are treated separately in genetic evaluations, but advantages may accrue to their joint evaluation. A good example is the system in pig breeding. Simplified breeding objectives are generally no longer appropriate and consequently becoming increasingly complex. The goal of selection for improved animal performance is to increase the profit of the production system; therefore, economic selection indices are now used in most livestock breeding programmes. Recent developments in dairy cattle breeding have focused on the incorporation of molecular information into genetic evaluations and on increasing the importance of longevity and health in breeding objectives to maximize the change in profit. For a genetic evaluation of meat yield (beef, pig, sheep), several types of information can be used, including data from performance test stations, records from progeny tests and measurements taken at slaughter. The standard genetic evaluation method of evaluation of growth or milk production has been the multi-trait animal model, but a test-day model with random regression is becoming the new standard, in sheep as well. Reviews of molecular genetics and pedigree analyses for performance traits in horses are described. Genome - wide selection is becoming a world standard for dairy cattle, and for other farm animals it is under development.
\end{abstract}

Genetic indices, farm animal, molecular genetics, genomic selection

Populations of farm animals are undergoing continuous selection in an attempt to improve economic efficiency of animal production. Established procedures are being refined as new techniques are developed and implemented. The aim of this review was to summarize new genetic approaches and techniques in the breeding of cattle, sheep, pigs, and horses.

\section{Cattle}

The most dramatic recent developments in dairy cattle breeding are the incorporation of molecular information into genetic evaluations for individual production traits and the revision of breeding objectives to increased emphasis placed on longevity and health.

Incorporation of genetic markers into genetic evaluation is beneficial especially in evaluations of young animals lacking individual or progeny performance information. Initially, several markers within, or in linkage disequilibrium, with QTLs (quantitative trait loci) identified by haplotype or single marker association mapping were utilized (Grapes et al. 2006; Liu et al. 2008; Boleckova et al. 2012a).

Investigations reporting QTLs for milk production traits include those of Khatkar et al. (2004), who found important QTLs for milk yield on chromosomes 6, 14 and 20, and Boichard et al. (2003) who found genome wide important QTLs affecting milk yield on chromosome 14. These associations were subsequently confirmed by Mai et al. (2010). Matejickova et al. (2013) confirmed the importance of QTLs on chromosome 6 and 14 (including aQTL at position $0 \mathrm{cM}$ on chromosome 14 affecting milk protein percentage) and authors also found addition significant QTLs affecting milk production traits on chromosomes 7, 11, 23. Grisart et al. (2004) identified gene DGAT1 on chromosome 14,

Address for correspondence:

Alena Svitakova

Institute of Animal Science

Pratelstvi 815, 104 01, Prague, Czech Republic
Phone: +420267009639

Fax: +420267710779

E-mail: svitakova.alena@vuzv.cz

http://actavet.vfu.cz/ 
and Rychtarova et al. (2014) identified genes BTN1A1, ORL1 and STAT1, all of which influenced milk production traits while DGAT1 and BTN1A1 affected reproductive traits as well. Boleckova et al. (2012b) reported that the PRL gene influenced milk production traits, while Signorelli et al. (2009) identified the GHR gene on chromosome 20 as a QTL for milk production traits.

The most frequently used SNP (single nucleotide polymorphism) chip for bull genotyping is the Illumina BovineSNP50 v2 BeadChip which includes 54,609 SNPs. The Illumina Bovine3K BeadChip, including 2,900 SNPs, is usable especially for female genotyping. Wiggans et al. (2012) reported that GEBV prediction reliability for bulls genotyped by the $50 \mathrm{~K}$ chip to be 0.04-0.06 higher than reliabilities for those same bulls genotyped by the 3 Kchip. For combination of information from both chips, imputation can be used. Szyda et al. (2013) investigated the possibility of reducing the number of assessed markers on accuracy and found that using only those 3,000 SNPs with the highest relationship to estimated milk production allowed reasonably good prediction of GEBV.

Several methods have been developed to incorporate information from SNP chips into prediction of genomic breeding value (GEBV) (Meuwissen et al. 2001). Methods include multistep procedures LS, BayesA, BayesB, RR-BLUP (Meuwissen et al. 2001), B-LASSO (Park and Casella 2008) and GBLUP (VanRaden 2008), as well as the singlestep procedure ssGBLUP (Misztal et al. 2009; Aguilar et al. 2010; Christensen and Lund 2010; Pribyl et al. 2012). The main advantage of incorporation of information from SNP chips into breeding value prediction is to increase reliability of prediction. Hayes et al. (2009) reported reliabilities of young bull GEBV prediction up to 0.67, depending inter alia on the heritability of the production trait. VanRaden et al. (2009) stated that reliabilities of GEBV predictions were on average 0.23 higher than reliabilities of pedigree based breeding value predictions. Thus, the use of genomic breeding values in comparison to conventional breeding values is expected to lead to a more rapid response to selection and more profitable breeding programmes (Schaeffer 2006; König et al. 2009; Pryce et al. 2010), thanks to higher reliability of GEBV prediction (Hayes et al. 2009) and shorter generation intervals. A disadvantage of multistep methods is the risk of bias in international evaluation, thanks to strong pre-selection in national breeding programs. Such bias could be transferred into international evaluation. Bias could be avoided in single step breeding value prediction in which genotyped and non-genotyped animals are included (Patry et al. 2013).

The best procedure appears to be ssGBLUP, because this method increases reliability of breeding value prediction for genotyped and non-genotyped animals as well (Christensen and Lund 2010). Dependent variables in ssGBLUP are phenotypic records. Pribyl et al. (2013) used, instead of phenotypic records, deregressed proofs (DRP) of bulls not having performance recorded daughters. They reported an increase of GEBV prediction reliabilities ranging from 0.53 vs. 0.63 for predictions without vs. with the incorporation of DRPs. Incorporation of bull DRPs is beneficial especially in small populations. National GEBV prediction procedures should undergo validation by comparing prediction of young bull GEBVs with EBVs of those same bulls after progeny testing and when DYD yields are used as the dependent variable. Validated reliability reflecting correlation of prediction to DYD in domestic conditions may then be calculated (Mäntysaari et al. 2010). For international evaluation, Sullivan and VanRaden (2009) developed the genomic multiple across country evaluation (GMACE) procedure.

Changes in the breeding objectives in recent years have focused especially on the incorporation of and increasing emphasis on functional traits such as reproductive and health traits, linear type traits, and longevity. These traits have an important impact on profitability of milk production and herd replacement. Wolfova et al. (2007) reported that longevity has a particularly strong economic impact. Zavadilova et al. (2009) reported 
heritabilities of 0.05 and 0.04 for actual and functional longevity in the Czech Fleckvieh. Tsuruta et al. (2005) reported heritabilities ranging from 0.08-0.1 in US Holsteins, similar to estimates of 0.08 and 0.11 reported by Meszaros et al. (2013) in the Pinzgau cattle. In the Czech Holsteins, heritability of functional longevity was 0.025 on a log scale and 0.041 on the trait as originally recorded (Pachova et al. 2005). Longevity is often reported to be associated with age at first calving (Ducrocq 2005; M'hamdi et al. 2010; Zavadilova and Stipkova 2013), udder linear traits (especially udder attachment, udder depth, teats) and angularity and body condition score (Sölkner and Petschina 1999; Strapak et al. 2005; Zavadilova et al. 2011a). Zavadilova and Stipkova (2012) reported higher correlations of longevity with functional rather than with actual longevity. It should be noted that linear scoring, especially in case of udder traits, can be influenced by the time of scoring (Kasap et al. 2014).

The most common reasons for cow culling are problems with reproduction and udder diseases. Days open and the interval from parturition to first service are the traits most often used as selection criteria, with heritabilities ranging from 0.02 to 0.1 (Wall et al. 2003; Andersen-Ranberg et al. 2005; Jamrozik et al. 2005; Sun et al. 2009; Zink et al. 2012; Zavadilova and Zink 2013).

Selection to improve udder health can be implemented through indirect selection for somatic cell count (SCC), somatic cell score (SCS) and linear scores for udder size and morphology. These traits have low to intermediate heritabilities (Nemcova et al. 2011). Direct selection on udder health is generally not possible because of the lack of recorded data (Zavadilova et al. 2011b). Nemcova et al. (2007) investigated the importance of linear udder traits and concluded that high SCS scores in cows were associated with deep udders, weak central ligaments and poor fore udder attachment.

For genetic evaluation of meat yield, several information sources can be used, including data from performance test stations, records from progeny tests (station or field) and measurements taken at slaughter. The most commonly used analytical method for evaluation is the multi-trait animal model, the traits being net gain (calculated as carcass weight divided by age), "SEUROP" carcass conformation score (grades S to P according to muscularity), fatness classes ( 1 - lean, 5 - very fat) and meat percentage (Schild et al. 2003).

Nesetrilova (2005) described the growth curve for the Czech Fleckvieh cattle up to 1,400 days of age using a multiphase growth model. Vesela et al. (2011) estimated the genetic indices of beef cattle production traits in the SEUROP system. Vostry et al. (2012a, 2014) described growth evaluation of beef bulls in performance testing stations. Svitakova et al. (2014) examined alternative measures of growth potential of bulls in testing stations, whether genetic index estimates of such traits changed over time and whether existing methods for performance testing were appropriate.

Bogdanovic et al. (2002) evaluated performance tests for Simmental bulls and found that selection based on an individual performance test was appropriate for traits of medium (e. g. growth) to higher heritability. In their study, daily gain during different time periods (before the test, during the test and over the lifetime) and weight (at the beginning of the test, monthly during the test and at the end of the test) was evaluated.

Duchacek et al. (2011) reported that the average breeding value of an Angus cattle population changed over the course of time, presumably reflecting a genetic change resulting from a cumulative response to selection.

The thoroughly researched multi-trait method of genetic analysis is common practice for evaluation of growth. The random regression test-day model (RR-TDM) method, however, has been more narrowly analysed (Albuquerque and Meyer 2001; Nobre et al. 2003a, b; Meyer 2005). Krejcova et al. (2007) compared these two models using data from performance test stations on breeding bulls and concluded that the more appropriate 
method of evaluation was RR-TDM. For using this method of calculation it is necessary to weigh bulls at regular and relatively frequent intervals (Pribyl et al. 2008). Genetic indices for beef production are often estimated only for beef cattle (Arango et al. 2002; Baldi et al. 2012).

\section{Pigs}

In genetic evaluation of pigs, production and reproductive traits are generally conducted separately. There are some arguments for simultaneous analysis of both groups of traits. Through additional information from genetic correlations between production and reproductive traits, the accuracy of genetic evaluation could be increased, even though heritabilities of reproductive traits are generally low. Furthermore, no single trait value, but the whole animal is selected and then joint evaluation of traits is natural way. Furthermore, breeding values for all traits would be predicted for all animals. The linear combination of these traits with economic weights would result in aggregate genotypic values that could be directly used for selection (Krupa and Wolf 2013). On the other hand, (Hermesch et al. 2000; Chen et al. 2003; Holm et al. 2004) have reported low (and antagonistic) genetic correlations between production and reproductive traits. This is in agreement with Arango et al. (2005) and Kapell et al. (2009), who reported relatively high antagonistic correlations. A general problem in comparing studies of growth traits of pigs is the substantial diversity in definition of growth traits. Estany et al. (2002a, b) reported that reproductive, production, and quality traits in pigs are probably not genetically independent.

The effect of service sire was analysed in some studies of reproductive traits. Wolf and Wolfova (2012a) examined the impact of including a service sire effect on litter size traits for Czech Large White and Czech Landrace sows. Three different animal models were evaluated for each litter size trait (total number of piglets born, born alive and weaned): (i) the service sire effect was included and the complete relationship matrix for all the animals (service sires and sows) was taken into account; (ii) the service sire effect was included as a random effect without inclusion of the relationship matrix; (iii) the service sire effect was omitted from the model. Using the residual variance as a criterion, both models including the service sire effect were slightly better than the model without this effect. Estimates of genetic indices were very similar for the two models including the service sire effect. The proportion of variance for service sire was in the range from 2 to $3 \%$ (standard error approx. 0.2\%) in the Czech Large White and 2\% (standard error approx. 0.3\%) in the Czech Landrace for all three litter size traits and all models. In results of other authors, proportion of variance in the number of piglets born attributable to service sires varied from 0.00 to 0.05 for models including the relationship matrix and from 0.00 to 0.03 for models without the relationship matrix (Serenius et al. 2003; Su et al. 2007; Köck et al. 2009).

A different approach to genetic evaluation of reproductive traits of pigs is to analyse alternative traits such as piglet losses. Wolf and Wolfova (2012b) studied the effect of service sire on the number of stillborn piglets and the number of piglets that died till weaning. Animal models with versus without a service sire effect were compared. Estimates of genetic indices were very similar for the two models. The heritability for the number of stillborn piglets was 0.06 for both breeds and both models, and the heritability for the number of piglets that died till weaning was 0.07 in the Czech Large White and 0.05 to 0.06 in the Czech Landrace. The proportion of variance due to the service sire was very low (between 0.8 and 1.6\%). Similar low heritabilities have been reported by other authors (Serenius et al. 2003; Su et al. 2007; Kapell et al. 2009; Chen et al. 2010). A general question is whether selection against piglet losses may be effective. Farrowing losses are probably caused mainly by biological factors, and the estimated heritability is very low. Furthermore, the number of stillborn piglets may be connected with the heterogeneity 
(within-litter standard deviation or variance) of individual piglet weight at birth. There are indications that a higher heterogeneity may be associated with a higher number of stillborn piglets (Huby et al. 2003; Wolf et al. 2008).

Nagyne-Kiszlinger et al. (2013) analysed the following reproductive traits: number of piglets born alive (NBA), gestation length (GL), farrowing interval (FI) and age at first insemination (AFI) for two purebred and two reciprocal crossbred populations using a two-trait model with repeatability, and with a two-trait model for age at first insemination. The heritabilities were 0.06 for all four populations, $0.06-0.09$ and $0.22-0.3$ for FI, NBA and GL, respectively. There were large differences between heritabilities of AFI in purebred $(0.28,0.26)$ and crossbred $(0.41,0.40)$ populations. Dube et al. $(2012)$ reported a heritability of 0.07 for NBA from a repeatability animal model.

Comparisons of different genetic index estimation methods for litter size are described by Skorput et al. (2014). The objective of that study was to estimate genetic indices for litter size of the Black Slavonian pigs using the repeatability, multiple trait, and random regression models. Estimated heritabilities were in the range from 0.03 to 0.26 . Kapell et al. (2011) used a Bayesian analysis for reproductive traits.

Wittenbourg et al. (2011) studied within litter variability of piglet birth weight and its relationship to piglet survival. The within sex sample variance of birth weights per litter was designated as a trait of the sow. Estimates of heritability for the different measures ranged from 11 to $12 \%$. Douglas et al. (2013) confirmed that the effect of low piglet birth weight was associated with poor growth performance in pigs from birth to slaughter.

Dall' Olio et al. (2013) studied the association between single nucleotide polymorphisms in candidate genes and reproductive traits in the Italian Large White sows. Association analyses were performed with the following traits: number of piglets born alive (NBA), number of stillborn piglets (NSB1), total number born (TNB1), NBAI estimated breeding values (EBVs) and NBA random residuals (RRs). SNPs in BMPR1B, FUT1, GPX5, RBP4, and TGFBR1 genes were identified. Mucha et al. (2013) reported associations between mutations in the EGF, AREG and LIF genes and NBA, the number of piglets alive at 21 days of age, the age of sows at first farrowing, and the interval between successive litters.

\section{Sheep}

Growth performance can be recorded under farm conditions (Wolc et al. 2011; Zishiri et al. 2014) or in test stations (Gorjanc et al. 2009a; Gamasaee et al. 2010), on live animals (Mandal et al. 2012; Zishiri et al. 2014) or on carcasses (Mortimer et al. 2014). Modern technologies such as ultrasound, computer tomography scanning (Milerski 2001; Junkuszew and Ringdorfer 2005; Maxa et al. 2007; Maximini et al. 2012) and video image analysis (Rius-Vilarrasa et al. 2009) can be used to assess body composition and carcass merit.

Variance components and genetic indices for measurements of body weight or growth can be estimated using single or multi-trait animal models (Gorjanc et al. 2009a; Mandal et al. 2012) or random regression models, if consecutive measurements are available (Kariuki et al. 2010; Wolc et al. 2011). Wolc et al. (2011) reported that direct heritability of growth traits tended to increase with advancing age, whereas the maternal genetic effect was reduced at older ages. The proportion of variance for permanent environmental effects was relatively stable across time. Eye muscle depth (m. longissimus dorsi) and back fat depth are recorded primarily in meat sheep (Maxa et al. 2007; Maximini et al. 2012).

Meat quality traits (meat tenderness, meat colour, polyunsaturated fat content, mineral content and muscle oxidative capacity) were found to be generally of moderate heritability by Mortimer et al. (2014). Exceptions were intramuscular fat (0.48), ultimate $\mathrm{pH}(0.08)$ and fresh meat colour (0.08-0.10). Jandasek et al. (2014) observed differences in physico- 
chemical and sensory characteristics of lamb meat between sire breeds. Several measures of meat quality appear to have the potential for inclusion into breeding objectives for meat breeds of sheep.

Greasy fleece weight, clean fleece weight, staple length, staple strength and fibre diameter at first or later shearing are traits found to be moderately heritable in Merino (Ciappesoni et al. 2013; Di et al. 2014) and Romney (Wuliji et al. 2011; Scobie et al. 2012) sheep. As reported by Krupova et al. (2009), wool production and quality traits currently have very low economic importance in selection programs.

Heritabilities of reproductive traits generally are low. The most frequently recorded traits are the number of lambs born, number of lambs born alive, number of lambs weaned, litter weight, ewe fertility, ovulation rate, ewe rearing ability and lamb survival. Fixed effects for lambing year or season and age of the ewe at lambing (Rashidi et al. 2011; Mohammadi et al. 2012; Boujenane et al. 2013) or age at lambing within parity (Skorput et al. 2011) are usually included in repeatability models, linear models (Mohammadi et al. 2012; Boujenane et al. 2013; Schmidova et al. 2014) and threshold models (Mohammadi et al. 2012).

Heritabilities for litter size (number of lambs born) range from 0.04 to 0.14 (Maxa et al. 2007; Rashidi et al. 2011; Mohammadi et al. 2012), and similar heritabilities have been reported for other reproductive traits (Mohammadi et al. 2012; Boujenane et al. 2013). Schmidova et al. (2014) observed that genetic variance components differed among breeds.

The economics of lamb meat production is profoundly influenced by the number of weaned lambs, which is related to ewe fecundity, but also to lamb survival. Lamb survival can be treated as a trait of the dam or a trait of the individual (Vostry and Milerski 2013). Estimates of direct heritability are in the range from 0.01 to 0.13 , while maternal heritability estimates range from 0.01 to 0.07 (Maxa et al. 2009; Vatankhah and Talebi 2009; Hatcher et al. 2010; Vostry and Milerski 2013).

Because a test-day model is more effective in accounting for the environmental variation within a lactation than a whole lactation model (Bauer et al. 2012), breeding values for milk yield of ewes have been predominantly estimated using this procedure (Oravcova et al. 2006; Bauer et al. 2012; Komprej et al. 2012, 2013). Lifetime production can also be analysed (Gorjanc et al. 2009b). In addition to random genetic and environmental effects, the effects of days-in-milk, test day (possibly including the effect of interactions with the flock), parity, age at lambing, litter size and the number of weaned lambs are usually included in models for genetic evaluation of milk production (Bauer et al. 2012). The month of lambing or the interval between lambing and the first test-day are other important sources of variation (Carta et al. 2009). The effect of the number of suckled lambs is evident only in breeds of low production level; whereas in high-producing breeds, a positive effect existed only on first test-day records of twin bearing ewes (Carta et al. 2009).

Heritabilities for dairy traits on a total lactation basis are low to moderate for milk, fat, and protein yields (Komprej et al. 2009; Bauer et al. 2012; Dimov 2013) and high for fat and protein percentages (Pelmus et al. 2014).

Duchemin et al. (2012) showed that utilization of molecular markers can improve current selection methods. For example, accuracies of GEBV for males at birth can be increased by 18 to $25 \%$ according to traits.

Attention is also paid to breeding for morphological characteristics of the udders in dairy sheep (Milerski et al. 2006; Rovai et al. 2009; Sadeghi et al. 2014).

Selection to increase the profit of a sheep breeding enterprise requires calculation of economic values (increased profit per unit of selection response) for each trait in the breeding objective. Such values have been calculated under specific economic conditions 
in different countries, as reported by Conington et al. (2004); Jones et al.(2004); FuerstWaltl and Baumung (2009); Krupova et al.(2009); Wolfova et al.(2009) and Wolfova et al. (2011a,b). Many investigations have shown that economic values of traits can be sensitive to market prices of sheep products and to differences in input costs. The market prices of animal products (milk or meat) are of higher importance in determining marginal economic values than prices for inputs, especially for the marginal economic value of milk and meat production traits (Krupova et al. 2013). The price of lamb is the most important factor influencing marginal economic values in meat sheep (Kosgey et al. 2003; Conington et al. 2004; Lôbo et al. 2011).

\section{Horses}

Horse breeding was focused on sports performance but for smaller populations of local breeds, knowledge of the genetic variability and maintaining a certain degree of diversity is now important. Modern molecular tools such as parentage testing using microsatellite genotyping are powerful in guiding management and conservation of horses (Galov et al. 2005). These authors evaluated nine microsatellite loci (HTG4, HTG7, HTG10, HMS2, HMS3, HMS6, VHL20, ASB2; AHT5) in 53 Posavina, 37 Croatian Coldblood and 33 Lipizzaner in Croatia. Results showed that all tested loci were highly polymorphic. Allelic diversity in the Lipizzaner was 4.78 standard error across loci, while the Posavina and the Croatian Coldblood had higher allelic diversities (approximately 7.0 across loci).

Mahrous et al. (2011) also analysed genetic variation using five microsatellite markers (AHT4, HTG10, ABS2, ABS23, and CA245) in three horse breeds in Egypt (Arabian, Thoroughbred, and Egyptian Native). Three of the microsatellites were highly polymorphic, the highest being HTG10. The lowest mean heterozygosity was 0.754 in the Arabian breed, while the highest was for the Thoroughbred at 0.829. Mitochondrial D-loop sequence variation among the Hucul horses from the Czech Republic was described by Czernekova et al. (2013). A700-bp fragment of the mtDNA D-loop region (positions 15,430-16,129) was sequenced. From 165 samples representing 15 maternal lines, 14 haplotypes of this D-loop hypervariable region were identified.

Another study involving the Hucul horse was performed by Stachurska et al. (2012) in Poland. The Hucul breed was included in the Global Strategy for the Management of Farm Animal Genetic Resources, which aims at preserving the animal gene pool in an unaltered state. Huculs are bay, black, blue dun, yellow dun, tobiano, and chestnut. Grey and chestnut Huculs have always been undesirable. The aim of the study was to determine the frequency of alleles affecting coat colours in the population. The examined loci were ASIP, MC1R, DUN, KIT, and STX17. The ASIP and MC1R loci, on ECA22 and ECA3, respectively, control the so-called basic colours (Marklund et al. 1996; Rieder et al. 2001). Stachurska et al. (2012) concluded that the genetic structure of the Hucul population was not constant and does not comply strictly with the preservation aim. Breeders prefer bay, non-diluted, and tobiano horses and it may lead to undesired changes in the allele frequency.

Pedigree analyses allow assessment of the extent of inbreeding and family structures within a population (Gutierrez et al. 2005). Pjontek et al. (2012) applied the technique to four endangered horse breeds in Slovakia. The most complete pedigrees were found for the Lipizzan and Shagya Arabian breeds. The mean values of inbreeding ranged from $2.67 \%$ for the Slovak Sport Pony to $6.26 \%$ for the Hucul. The mean inbreeding coefficients in the Lipizzan and Shagya Arabian were $4.02 \%$ and $3.95 \%$, respectively.

In Czech populations of cold-blooded Norik, Silesian Norik and Czech-Moravian Belgian horses, Vostry et al. (2011) found the mean inbreeding values of 1.51, 3.23 and $3.53 \%$, respectively. Vincente et al. (2012) reported a much higher mean inbreeding coefficient, $9.92 \%$ for all registered animals, for the Lusitano horse. The effective number 
of founders and the number of ancestors contributing to the current genetic pool were 27.5 and 11.7, respectively. Much higher effective numbers of founders and ancestors, 94 and 32, respectively, were reported in the Lipizzan horse by Pjontek et al. (2012).

Galov et al. (2013) examined the genetic structure and admixture between Posavina and Croatian Coldblood in contrast to the Lipizzan horses from Croatia. The Posavina and Croatian Coldblood are Croatian autochthonous horse breeds with interwoven breeding histories. In contrast, the Lipizzan breed has the oldest formalized breeding program in Croatia and no record of recent genetic introgression from other breeds. Results showed that different breeding schemes and histories had a strong and measurable impact on the population's genetic structure within and between the three breeds. The Lipizzan showed genetic differentiation from the other two breeds.

The Old Kladruber horse is an autochthonous breed that is recognized as a genetic resource in the Czech Republic. Vostry et al. (2012b) studied the occurrence of dermal melanoma within the breed and reported that the white colour in greying white horses, one of the basic colour varieties in breed, is a result of progressive greying that is the loss of coat pigmentation with age. Increased susceptibility to dermal melanoma has been associated with greying of white horses by Fleury et al. (2000) and Heizerling et al. (2001).

Further studies of the Old Kladruber horse by Vostry et al. (2012c) were focused on selection for important conformation traits and reduction in the number of recorded characteristics from the present 36 to 24 traits with regard to a high number of described traits and a lower number of individuals. In order to reduce the number of the described traits, they advised omitting traits with less heritability than 0.10 and traits highly genetically correlated with other recorded traits.

\section{Summary}

More appropriate approaches for breeding value prediction for various species have been identified. Selection programs aim to increase the profit for breeders; therefore many authors focused on that topic. Genome-wide selection has become a world standard for dairy cattle breeding. This method takes proper account of information from relatives in assessing the genetic merit of individuals. For some classes of farm animals, molecular genetic approaches include seeking to identify new QTLs and developing genome-wide selection programmes. Primary impediments to further development include the high cost of high-density SNP arrays and difficulty in finding well-structured reference populations to estimate SNP effects for traits that are routinely measured or are costly to record. In the future, research is likely to be expanded to genetic improvement in health status of animals, e.g. mastitis in dairy cows. Longevity, robustness and fertility are also likely to increase in importance in livestock breeding programs.

\section{Acknowledgements}

The review was supported by Ministry of Agriculture of the Czech Republic, Project No. RO0714 and Project No. SV14-67-21360, SGS FAPPZ of Ministry of Education, Youth and Sport of the Czech Republic.

\section{References}

Aguilar I, Misztal I, Johnson DL, Legarra A, Tsuruta S, Lawlor TJ 2010: Hot topic: A unified approach to utilize phenotypic, full pedigree, and genomic information for genetic evaluation of Holstein final score. J Dairy Sci 93: $743-752$

Albuquerque LG, Meyer K 2001: Estimates of covariance functions for growth from birth to 630 days of age in Nelore cattle. J Anim Sci 79: 2776-2789

Andersen-Ranberg IM, Klemetsdal G, Heringstad B, Steine T 2005: Heritabilities, genetic correlations, and genetic change for female fertility protein yield in Norwegian dairy cattle. J Dairy Sci 88: $348-355$ 
Arango JA, Cundiff LV, Van Vleck LD 2002: Genetic parameters for weight, adjusted for body condition score, height, and body condition score in beef cows. J Anim Sci 80: 3112-3122

Arango JA, Misztal I, Tsuruta S, Culbertson M, Herring W 2005: Threshold-linear estimation of genetic parameters for farrowing mortality, litter size, and test performance of Large White sows. J Anim Sci 83: 499-506

Baldi F, Albuquerque LG, Cyrillo JNSG, Branco RH, Oliveira Junior BC, Mercandate MEZ 2012: Genetic parameter estimates for live weight and daily live weight gain obtained for Nellore bulls in a test station using different models. Livest Sci 144: 148-156

Bauer J, Milerski M, Přibyl J, Vostrý L 2012: Estimation of genetic parameters and evaluation of test-day milk production in sheep. Czech J Anim Sci 57: 522-528

Bogdanovic V, Djurdjevic R, Petrovic M 2002: Changes in components of variance of growth traits in performance testing of simmental bulls. Seventh World Congress on Genetic Applied to Livestock Production, August 1923, Montpellier

Boichard D, Grohs C, Bourgeois F, Cerqueira F, Faugeras R, Neau A, Rupp R, Amigues Y, Boscher MY, Leveziel H 2003: Detection of genes influencing economic traits in three French dairy cattle breeds. Genet Sel Evol 35 : 77-101

Boleckova J, Christensen OF, Sørensen P, Sahana G 2012a: Strategies for haplotype-based association mapping in a complex pedigreed population. Czech J Anim Sci 57: 1-9

Boleckova J, Matejickova J, Stipkova M, Kyselova J, Barton L 2012b: The association of five polymorphisms with milk production traits in Czech Fleckvieh cattle. Czech J Anim Sci 57: 45-53

Boujenane I, Chikhi A, Sylla M, Ibnelbachyr M 2013: Estimation of genetic parameters and genetic gains for reproductive traits and body weight of D'man ewes. Small Ruminant Res 113: 40-46

Carta A, Casu S, Salaris S 2009: Invited review: Current state of genetic improvement in dairy sheep. J Dairy Sci 92: $5814-5833$

Chen CY, Misztal I, Tsuruta S, Herring WO, Holl J, Culbertson M 2010: Genetic analyses of stillbirth in relation to litter size using random regression models. J Anim Sci 88: 3800-3808

Chen P, Baas TJ, Mabry JW, Koehler KJ 2003: Genetic correlations between lean growth and litter traits in US Yorkshire, Duroc, Hampshire, and Landrace pigs. J Anim Sci 81: 1700-1705

Christensen OF, Lund MS 2010: Genomic prediction when some animals are not genotyped. Genet Sel Evol 42: 2

Ciappesoni G, Goldberg V, Gimeno D 2013: Estimates of genetic parameters for worm resistance, wool and growth traits in Merino sheep of Uruguay. Livest Sci 157: 65-74

Conington J, Bishop SC, Waterhouse A, Simm G 2004: A bioeconomic approach to derive economic values for pasture-based sheep genetic improvement programs. J Anim Sci 8: 1290-1304

Czerneková V, Kott T, Majzlík I 2013: Mitochondrial D-loop sequence variation among Hucul horse. Czech J Anim Sci 58: 437-442

Di J, Ainiwaer L, Xu XM, Zhang YH, Yu LJ, Li WC 2014: Genetic trends for growth and wool traits of Chinese superfine Merino sheep using a multi-trait animal model. Small Ruminant Res 117: 47-51

Dall'Olio S, Fontanesi L, Buttazzoni L, Biaocco C, Gallo M, Russo V 2013: Association study between single nucleotide polymorphisms in candidate genes and reproduction traits in Italian Large White sows. Livest Sci 155: $172-179$

Dimov G 2013: Genetic estimates at monthly and short-cut control of the sheep milk production. Agrarni Nauki 5: $37-41$

Douglas SL, Edwards SA, Sutcliffe E, Knap PW, Kyriazakis I 2013: Identification of risk factors associated with poor lifetime growth performance in pigs. J Anim Sci 91: 4123-4132

Dube B, Mulugeta SD, Dzama K 2012: Estimation of genetic and phenotypic parameters for sow productivity traits in South African Large White pigs. S Afr J Anim Sci 42: 389-397

Duchacek J, Pribyl J, Stadnik L, Vostry L, Beran J, Stolc L 2011: Stability of Aberdeen Angus breeding values in the Czech Republic from 1997 to 2007. Czech J Anim Sci 56: 509-520

Duchemin SI, Colombani C, Legarra A, Baloche G, Larroque H, Astruc JM, Barillet F, Robert-Granie C, Manfredi E 2012: Genomic selection in the French Lacaune dairy sheep breed. J Dairy Sci 95: 2723-2733.

Ducrocq V 2005: An improved model for the French genetic evaluation of dairy bulls on length of productive life of their daughters. Anim Sci 80: 249-256

Estany J, Villalba D, Tibau J, Soler J, Babot D, Noguera JL 2002a: Correlated response to selection for litter size in pigs: I. Growth, fat deposition, and feeding behaviour traits. J Anim Sci 80: 2556-2565

Estany J, Villalba D, Tor M, Cubilo D, Noguera JL 2002b: Correlated response to selection for litter size in pigs: II. Carcass, meat, and fat quality traits. J Anim Sci 80: 2566-2573

Fleury C, Berard F, Balme B, Thomas L 2000: The study of cutaneous melanomas in Camarque-type gray skinned horses (1): clinical-pathological characterization. Pigment Cell Res 13: 39-46

Fuerst-Waltl B, Baumung R 2009: Economic values for performance and functional traits in dairy sheep. Ital J Anim Sci 8: $341-357$

Galov A, Byrne K, Duras-Gomerčić M, Gomerčić T, Nushol Z, Vincek D, Kocijan I, Tadić Z, Benković T, Bašić I, Funk SM 2005: Effectiveness of nine polymorphic microsatellite markers in parentage testing in Posavina, Croatian Coldblood and Lipizzaner horse breeds in Croatia. Livest Production Sci 93: 277-282

Galov A, Byrne K, Gomerčić T, Duras M, Arbanasić H, Sindičić M, Mihelić D, Kovačić A, Funk SM 2013: 
Genetic structure and admixture between the Posavina and Croatian coldblood in contrast to Lipizzan horse from Croatia. Czech J Anim Sci 58: 71-78

Gamasaee VA, Hafezian SH, Ahmadi A, Baneh H, Farhadi A, Mohamadi A 2010: Estimation of genetic parameters for body weight at different ages in Mehraban sheep. Afr J Biotechnol 9: 5218-5223

Gorjanc G, Drasler D, Birtic D, Kompan D 2009a: Growth performance of station tested rams in Slovenia. Italian J Anim Sci 8: 74-76

Gorjanc G, Gantner V, Kompan D 2009b: The lifetime production of Bovec and Improved Bovec sheep breeds. Mljekarstvo 59: 114-124

Grapes L, Firat MZ, Dekkers JCM, Rothschild MF, Fernando RL 2006: Optimal haplotype structure for linkage disequilibrium-based fine mapping of quantitative trait loci using identity by descent. Genetics 172: 1955-1965

Grisart B, Farnir F, Karim L, Cambisano N, Kim JJ, Kvasz A, Mni M, Simon P, Frère JM, Coppieters W, Georges M 2004: Genetic and functional confirmation of the causality of the DGAT1 K232A quantitative trait nucleotide in affecting milk yield and composition. Proc Natl Acad Sci USA 101: 2398-2403

Gutierrez JP, Marmi J, Goyache F, Jordana J 2005: Pedigree information reveals moderate to high levels of inbreeding and a week population structure in the endangered Catalonian donkey breed. J Anim Breed Genet 122: $378-386$

Hatcher S, Atkins KD, Safari E 2010: Lamb survival in Australian Merino Sheep: A genetic analysis. J Anim Sci 88: $3198-3205$

Hayes BJ, Bowman PJ, Chamberlain AJ, Goddard ME 2009: Invited review: Genomic selection in dairy cattle: progress and challenges. J Dairy Sci 92: 433-443

Heizerling LM, Feige K, Rieder S, Akens MK, Dummer R, Stranzinger G, Moelling K 2001: Tumor regression induced by intratumoral injection of DNA coding for human interleukin 12 into melanoma metastase in grey horses. J Mol Med 78: 692-702

Hermesch S, Luxford BG, Graser HU 2000: Genetic parameters for lean meat yield, meat quality, reproduction and feed efficiency traits for Australian pigs. 3. Genetic parameters for reproduction traits and genetic correlations with production, carcase and meat quality traits. Livest Production Sci 65: 261-270

Holm B, Bakken M, Klemetsdal G, Vangen O 2004: Genetic correlations between reproduction and production traits in swine. J Anim Sci 82: $3458-3464$

Huby M, Gogue J, Maignel L, Bidanel JP 2003: Genetic correlations between litter size and weights, piglet weight variability and piglet survival from birth to weaning (in French). Journées Rech Porcine 35: 293-300

Jamrozik J, Fatehi J, Kistemaker GJ, Schaeffer LR 2005: Estimates of genetic parameters for Canadian Holstein female reproduction traits. J Dairy Sci 88: 2199-2208

Jandasek J, Milerski M, Lichovnikova M 2014: Effect of sire breed on physico-chemical and sensory characteristics of lamb meat. Meat Sci 96: 88-93

Jones HE, Amer PR, Lewis RM, Emmans GC 2004: Economic values for changes in carcass lean and fat weights at a fixed age for terminal sire breeds of sheep in the UK. Livest Production Sci 89: 1-17

Junkuszew A, Ringdorfer F 2005: Computer tomography and ultrasound measurement as methods for the prediction of the body composition of lambs. Small Ruminant Res 56: 121-125

Kapell DNRG, Ashworth CJ, Knap PW, Roehe R 2011: Genetic parameters for piglet survival, litter size and birth weight or its variation within litter in sire and dam lines using Bayesian analysis. Livest Sci 135: 215-224

Kapell DNRG, Ashworth CJ, Walling GA, Lawrence AB, Edwards SA, Roehe R 2009: Estimation of genetic associations between reproduction and production traits based on a sire and dam line with common ancestry. Animal 3: 1354-1362

Kariuki CM, Ilatsia ED, Wasike CB, Kosgey IS, KahiAK 2010: Genetic evaluation of growth of Dorper sheep in semi-arid Kenya using random regression models. Small Ruminant Res 93:126-134

Kasap A, Skorput D, Kompan D, Gorjanc G, Mioc B, Potocnik K 2014: The effect of time elapsed from milking to scoring on udder linear scores and estimation of genetic parameters. Vet Archiv 84: 9-18

Khatkar MS, Thomson PC, Tammen I, Raadsma HW 2004: Quantitative trait loci mapping in dairy cattle: review and meta-analysis. Genet Sel Evol 36: 163-190

Köck A, Baumung R, Furst-Waltl B 2009: Influence of service sires on litter size and impact of the additional consideration of inbreeding on heritability in Large White and Landrace (in Deutsch). Zuchtungskunde 81: 77-85

Komprej A, Gorjanc G, Kompan D, Kovač M 2009: Covariance components by a repeatability model in Slovenian dairy sheep using test-day records. Czech J Anim Sci 54: 426-434

Komprej A, Gorjanc G, Kompan D, Kovač M 2012: Lactation curves for milk yield, fat, and protein content in Slovenian dairy sheep. Czech J Anim Sci 57: 231-239

Komprej A, Malovrh Š, Gorjanc G, Kompan D, Kovač M 2013: Genetic and environmental parameters estimation for milk traits in Slovenian dairy sheep using random regression model. Czech J Anim Sci 58: 125-135

König S, Simianer H, Willam A 2009: Economic evaluation of genomic breeding programs. J Dairy Sci 92: 382-391

Kosgey IS, Van Arendonk JAM, Baker RL 2003: Economic values for traits of meat sheep in medium to high production potential areas of the tropics. Small Ruminant Res 50: 187-202

Krejcova H, Mielenz N, Pribyl J, Schüler L 2007: Estimation of genetic parameters for daily gains of bulls with multi-trait and random regression models. Arch Tierzucht 50: 37-46 
Krupa E, Wolf J 2013: Simultaneous estimation of genetic parameters for production and litter size traits in Czech Large White and Czech Landrace pigs. Czech J Anim Sci 58: 429-436

Krupova Z, Krupa E, Wolfova M 2013: Impact of economic parameters on economic values in dairy sheep. Czech J Anim Sci 58: 21-30

Krupová Z, Wolfová M, Wolf J, Oravcová M, Margetín M, Peškovičová D, Krupa E, Daňo J 2009: Economic values for dairy sheep breeds in Slovakia. Asian Austral J Anim 22: 1693-1702

Liu N, Zhang K, Zhao H 2008: Haplotype-association analysis. Adv Genet 60: 335-405

Lôbo RNB, Pereira IDC, Facó O 2011: Economic values for production traits of Morada Nova meat sheep in a pasture based production system in semi-arid Brazil. Small Ruminant Res 96: 93-100

M'hamdi N, Aloulou R, Brar SK, Bouallegue M, Ben Hamouda M 2010: Study on functional longevity of Tunisian Holstein dairy cattle using a Weibull proportional hazards model. Livest Sci 132: 173-176

Mahrous KF, Hassanane M, Mordy MA, Shafey HI, Hassan N 2011: Genetic variations in horse using microsatellite markers. J Genetic Engineering and Biotechnology 9: 103-109

Mai MD, Rychtarova J, Zink V, Lassen J, Gludbrandsten B 2010: Quantitative trait loci for milk production and functional traits in Danish cattle breeds. J Anim Breed Genet 127: 469-473

Mandal A, Dass G, Rout PK 2012: Model comparisons for estimation of genetic parameters of pre-weaning daily weight gains in Muzaffarnagari sheep. Small Ruminant Res 106: 118-124

Mäntysaari E, Liu Z, VanRaden P 2010: Interbull validation test for genomic evaluations. Interbull Bulletin 41: $17-22$

Marklund LS, Moller MJ, Sandberg K, Andersson L 1996: A missense mutation in the gene for melanocytestimulating hormone receptor (MC1R) is associated with chestnut coat colour in horses. Mamm Genome 7: 895-899

Matejicková J, Stipková M, Sahana G, Kott T, Kyselova J, Matejicek A, Kottova B, Sefrova J, Krejcova M, Melcova S 2013: QTL mapping for production traits in Czech Fleckvieh cattle. Czech J Anim Sci 58: 396-403

Maxa J, Norberg E, Berg P, Pedersen J 2007: Genetic parameters for growth traits and litter size in Danish Texel, Shropshire, Oxford Down and Suffolk. Small Ruminant Res 68: 312-317

Maxa J, Sharifi AR, Pedersen J, Gauly M, Simianer H, Norberg E 2009: Genetic parameters and factors influencing survival to twenty-four hours after birth in Danish meat sheep breeds. J Anim Sci 87: 1888-1895

Maximini L, Brown DJ, Baumung R, Fuerst-Waltl B 2012: Genetic parameters of ultrasound and computer tomography scan traits in Austrian meat sheep. Livest Sci 146: 168-174

Meszaros G, Kadlecik O, Kasarda R, Sölkner J 2013: Analysis of longevity in the Slovak Pinzgau populationextension to the animal model. Czech J Anim Sci 58: 289-295

Meuwissen THE, Hayes BJ, Goddard ME 2001: Prediction of total genetic value using genome-wide dense marker maps. Genetics 157: 1819-1829

Meyer K 2005: Random regression analyses using B-splines to model growth of Australian Angus cattle. Genet Sel Evol 37: 473-500

Milerski M 2001: In vivo assessment of meatiness and fattiness of Charolais ram-lambs. Czech J Anim Sci 46: 275-280

Milerski M, Margetín M, Čapistrák A, Apolen D, Špánik J, Oravcová M 2006: Relationships between external and internal udder measurements and the linear scores for udder morphology traits in dairy sheep. Czech J Anim Sci 51: 383-390

Misztal I, Legarra A, Aguilar I 2009: Computing procedures for genetic evaluation including phenotypic, full pedigree, and genomic information. J Dairy Sci 92: 4648-4655

Mohammadi H, Shahrbabak MM, Shahrbabak HM, Vatankhah M 2012: Estimation of genetic parameters of reproductive traits in Zandi sheep using linear and threshold models. Czech J Anim Sci 57: 382-388

Mortimer SI, Van der Werf JHJ, Jacob RH, Hopkins DL, Pannier L, Pearce KL, Gardner GE, Warner RD, Geesink GH, Edwards JEH, Ponnampalam EN, Ball AJ, Gilmour AR, Pethick DW 2014: Genetic parameters for meat quality traits of Australian lamb meat. Meat Sci 96: 1016-1024

Mucha A, Ropka-Molik K, Piorkowska K, Tyra M, Oczkowicz M 2013: Effect of EGF, AREG and LIF genes polymorphisms on reproductive traits in pigs. Anim Reprod Sci 137: 88-92

Nagyne-Kiszlinger H, Farkas J, Kover G, Nagy I 2013: Selection for reproduction traits in Hungarian pig breeding in a two-way cross. Anim Sci Pap Rep 31: 315-322

Nemcova E, Stipkova M, Zavadilova L 2011: Genetic parameters for linear type traits in Czech Holstein cattle. Czech J Anim Sci 4: 157-162

Nemcova E, Stipkova M, Zavadilova L, Bouska J, Vacek M 2007: The relationship between somatic cell count, milk production and six linearly scored type traits in Holstein cows. Czech J Anim Sci 12: 437-446

Nesetrilova H 2005: Multiphasic growth models for cattle. Czech J Anim Sci. 50: 347-354

Nobre PRC, Misztal I, Tsuruta S, Bertrand JK, Silva LOC, Lopes PS 2003a: Analyses of growth curves of Nellore cattle by multiple-trait and random regression models. J Anim Sci 81: 918-926

Nobre PRC, Misztal I, Tsuruta S, Bertrand JK, Silva LOC, Lopes PS 2003b: Genetic evaluation of growth in Nellore cattle by multiple-trait and random regression models. J Anim Sci 81: 917-932

Oravcová M, Margetín M, Peškovičova D, Daňo J, Milerski M, Hetényi L, Polák P 2006: Factors affecting milk yield and ewe's lactation curves estimated with test-day models. Czech J Anim Sci 51: 183-490 
Pachova E, Zavadilova L, Sölkner J 2005: Genetic evaluation of the length of productive life in Holstein cattle in the Czech Republic. Czech J Anim Sci 50: 493-498

Patry C, Hossein J, Ducrocq V 2013: Effects of a national genomic preselection on the international genetic evaluations. J Dairy Sci 96: 3272-3284

Park T, Casella G 2008: The Bayesian LASSO. J Am Stat Assoc 103: 681-686

Pjontek J, Kadlečík O, Kasarda R, Horný M 2012: Pedigree analysis in four Slovak endangered horse breeds. Czech J Anim Sci 57: 54-64

Pelmus RS, Pistol GC, Lazar C, Gras MA, Ghita E 2014: Estimation of genetic parameters for milk traits in Romanian local sheep breed. Revista Mvz Cordoba 19: 4033-4040

Pribyl J, Haman J, Kott T, Pribylova J, Simeckova M, Vostry L, Zavadilova L, Cermak V, Ruzicka Z, Splichal J, Verner M, Motycka J, Vondrasek L 2012: Single-step prediction of genomic breeding value in a small dairy cattle population with strong import of foreign genes. Czech J Anim Sci 57: 151-159

Pribyl J, Madsen P, Bauer J, Pribylova J, Simečkova M, Vostry L, Zavadilova L 2013: Contribution of domestic production records, Interbull estimated breeding values, and single nucleotide polymorphism genetic markers to the single-step genomic evaluation of milk production. J Dairy Sci 95: 1865-1873

Pribyl J, Pribylova J, Krejcova H, Mielenz N 2008: Comparison of different traits to evaluate the growth of bulls. Czech J Anim Sci 53: 273-283

Pryce JE, Goddard ME, Raadsma HW, Hayes BJ 2010: Deterministic models of breeding scheme designs that incorporate genomic selection. J Dairy Sci 93: 5455-5466

Rashidi A, Mokhtari MS, Esmailizadeh AK, Asadi Fozi M 2011: Genetic analysis of ewe productivity traits in Moghani sheep. Small Ruminant Res 96: 11-15

Rieder S, Taourit S, Mariat D, Langlois B, Guérin G 2001: Mutations in the agouti (ASIP), the extension (MC1R), and the brown (TYRP1) loci and their association to coat colour phenotypes in horses (Equus caballus). J Mammalian Genome 12: 450-455

Rius-Vilarrasa E, Bünger L, Maltin C, Matthews KR, Roehe R 2009: Evaluation of Video Image Analysis (VIA) technology to predict meat yield of sheep carcasses on-line under UK abattoir conditions. Meat Sci 82: 94-100

Rovai M, Caja G, Such X 2009: Evaluation of udder cisterns and effects on milk yield of dairy ewes. J Dairy Sci 91: 4622-4629

Rychtarova J, Sztankoova Z, Kyselova J, Zink V, Stipkova M, Vacek M, Stolc L 2014: Effect of DGAT1, BTNA1A1, ORL1 and STAT1 genes on milk production and reproduction traits in the Czech Fleckvieh breed. Czech J Anim Sci 59: 45-53

Sadeghi S, Rafat A, Bohlouli M 2014: Effect of crossbreeding on linear udder scores and their phenotypic relationships in Iranian fat-tailed ewe's. Biotechnol Anim Husb 30: 61-77

Schaeffer LR 2006: Strategy for applying genome-wide selection in dairy cattle. J Anim Breed Genet 123: 218-223

Schild HJ, Niebel E, Gotz KU 2003: Across country genetic evaluation of beef traits in Middle European dual purpose breeds. Interbull Bulettin 31: 158-162

Schmidova J, Milerski M, Svitakova A, Vostry L, Novotna A 2014: Estimation of genetic parameters for litter size in Charollais, Romney, Merinolandschaf, Romanov, Suffolk, Sumava and Texel breeds of sheep. Small Ruminant Res 119: 33-38

Scobie DR, Bray AR, Smith MC, Woods JL, Morris CA, Hickey SM 2012: Wool staple tenacity in New Zealand Romney sheep: heritability estimates, correlated traits, and direct response to selection. Anim Prod Sci 52: 448-455

Serenius T, Sevon-Aimonen ML, Mantysaari EA 2003: Effect of service sire and validity of repeatability model in litter size and farrowing interval of Finnish Landrace and Large White populations. Livest Production Sci 81: $213-222$

Signorelli F, Orru L, Napolitano F, De Matteis G, Scata M C, Catilo G, Marchitelli C, Moioli, B 2009: Exploring polymorphisms and effects on milk traits on the DGAT1, SCD1 and GHR genes in four cattle breeds. Livest Sci 125: 74-79

Skorput D, Gorjanc G, Dikic M, Lukovic Z 2014: Genetic parameters for litter size in Black Slavonian pigs. Span J Agric Res 12: 89-97

Skorput D, Kasap A, Gorjanc G 2011: Estimation of variance components for litter size in the first and later parities in improved Jezersko-Solcava sheep. Agric Conspec Sci 76: 337-340

Sölkner J, Petschina R 1999: Relationship between type traits and longevity in Australian Simmental cattle. Interbull Bulletin 21: 91-96

Stachurska A, Brodacki A, Grabowska J 2012: Allele frequency in loci which control coat colours in Hucul horse population. Czech J Anim Sci 57: 178-186

Strapak P, Candrak J, Amann J 2005: Relationship between longevity and selected production, reproduction and type traits. Czech J Anim Sci 50: 1-6

Su G, Lund MS, Sorensen D 2007: Selection for litter size at day five to improve litter size at weaning and piglet survival rate. J Anim Sci 85: 1385-1392

Sullivan PG, VanRaden PM 2009: Development of genomic GMACE. Interbull Bulletin 40: 157-161

Sun C, Madsen P, Nielsen US, Zhang Y, Lund MS, Su G 2009: Comparison between a sire model and an 
animal model for genetic evaluation of fertility traits in Danish Holstein population. J Dairy Sci 92: 4063 4071

Svitakova A, Bauer J, Pribyl J, Vesela Z, Vostry L 2014: Changing of genetic parameters and assesing the suitability of the test method over time. Czech J Anim Sci 59: 19-25

Szyda J, Zukowski K, Kamiński S, Zarnecki A 2013: Testing different single nucleotide polymorphisms selection strategies for prediction of genomic breeding values in dairy cattle based on low density panels. Czech J Anim Sci 58: 136-145

Tsuruta S, Misztal I, Tawlor 2005: Changing definitions of productive life in US Holsteins. Effect on genetic correlations. J Dairy Sci 88: 1156-1165

VanRaden PM 2008: Efficient methods to compute genomic predictions. J Dairy Sci 91: 4414-4423

VanRaden PM, Van Tassell CP, Wiggans GR, Sonstegard TS, Schnabel RD, Taylor JF, Schenkel FS 2009: Invited review: Reliability of genomic predictions for North American Holstein bulls. J Dairy Sci 92: 16-24

Vatankhah M, Talebi MA 2009: Genetic and non-genetic factors affecting mortality in Lori-Bakhtiari lambs. Asian Austral J Anim 22: 259-464

Vesela Z, Vostry L, Safus P 2011: Linear and linear-threshold model for genetic parameters for SEUROP carcass traits in Czech beef cattle. Czech J Anim Sci 56: 414-425

Vincente AA, Carolino N, Gama LT 2012: Genetic diversity in the Lusitano horse breed assessed by pedigree analysis. J Livest Sci 148: 16-25

Vostry L, Capkova Z, Pribyl J, Hofmanova B, Vostra-Vydrova H, Mach K 2011: Population structure of Czech cold-blooded breeds of horses. Arch Tierz 54: 1-9

Vostry L, Hofmanova B, Vostra Vydrova H, Pribyl J, Majzlik I 2012c: Estimation of genetic parameters for melanoma in the Old Kladruber horse. Czech J Anim Sci 57: 75-82

Vostry L, Milerski M 2013: Genetic and non-genetic effects influencing lamb survivability in the Czech Republic. Small Ruminant Res 113: 47-54

Vostry L, Pribyl J, Simecek P 2012b: Reduction of traits for genetic evaluation of linear described traits in the Old Kladruber horse. Czech J Anim Sci 57: 160-170

Vostry L, Vesela Z, Pribyl J 2012a: Genetic parameters for growth of young beef bulls. Arch Tierz 55: 245-254

Vostry L, Vesela Z, Krupa E 2014: Genetic evaluation of the growth of beef bulls at a performance test station. J Anim Feed Sci 23: 37-44

Wall E, Brotherstone S, Woolliams JA, Banos G, Coffey MP 2003: Genetic evaluation of fertility using direct and correlated traits. J Dairy Sci 86: 4093-4102

Wiggans GR, Cooper TA, VanRaden PM, Olson KM, Tooker ME 2012: Use of the Illumina Bovine3K BeadChip in dairy genomic evaluation. J Dairy Sci 95: 1552-1558

Wittenbourg D, Guiard V, Teuscher F, Reinsch N 2011: Analysis of birth weight variability in pigs with respect to liveborn and total born offspring. J Anim Breed Genet 128: 35-43

Wolc A, Barczak E, Wojtowski J, Slosarz P, Szwaczkowski T 2011: Genetic parameters of body weight in sheep estimated via random regression and multi-trait animal models. Small Ruminant Res 100: 15-18

Wolf J, Wolfova M 2012a: Effect of service sire on litter size traits in Czech Large White and Landrace pigs. Czech J Anim Sci 57: 220-230

Wolf J, Wolfova M 2012b: Genetic parameters including the service sire effect for the sow traits stillbirth and piglet losses in Czech Large White and Landrace. Czech J Anim Sci 57: 402-409

Wolf J, Zakova E, Groeneveld E 2008: Within-litter variation of birth weight in hyperprolific Czech Large White sows and its relation to litter size traits, stillborn piglets and losses until weaning. Livest Sci 115: 195-205

Wolfova M, Wolf J, Kvapilik J, Kica J 2007: Selection for profit in cattle: I. Economic weights for purebred dairy cattle in the Czech Republic. J Dairy Sci 90: 2442-2455

Wolfova M, Wolf J, Milerski M 2009: Calculating economic values for growth and functional traits in non-dairy sheep. J Anim Breed Genet 126: 480-491

Wolfova M, Wolf J, Milerski M 2011a: Economic weights of production and functional traits for Merinolandschaf, Romney, Romanov and Sumavska sheep in the Czech Republic. Small Ruminant Res 99: 25-33

Wolfova M, Wolf J, Milerski M 2011b: Calculating economic weights for sheep sire breeds used in different breeding systems. J Anim Sci 89: 1698-1711

Wuliji T, Dodds KG, Andrews RN, Turner R 2011: Selection response to fleece weight, wool characteristics, and heritability estimates in yearling Romney sheep. Livest Sci 135: 26-31

Zavadilova L, Nemcova E, Stipkova M 2011a: Effect of type traits on functional longevity of Czech Holstein cows estimated from a Cox proportional hazards models. J Dairy Sci 94: 4090-4099

Zavadilova L, Nemcova E, Stipkova M, Bouska J 2009: Relationship between longevity and conformation traits in Czech Fleckvieh cows. Czech J Anim Sci 54: 387-394

Zavadilova L, Stipkova M 2012: Genetic correlations between longevity and conformation traits in the Czech Holstein population. Czech J Anim Sci 57: 125-136

Zavadilova L, Stipkova M 2013: Effect of age at first calving on longevity and fertility traits for Holstein cattle. Czech J Anim Sci 58: 47-57

Zavadilova L, Wolf J, Stipkova M, Nemcova E, Jamrozik J 2011b: Genetic parameters for somatic cell score in 
the first three lactations of Czech Holstein and Fleckvieh breeds using a random regression model. Czech J Anim Sci 56: 251-260

Zavadilova L, Zink V 2013: Genetic relationship of functional longevity with female fertility and milk production traits in Czech Holsteins. Czech J Anim Sci 58: 554-565

Zink V, Lassen J, Stipková M 2012: Genetic parameters for female fertility and milk production traits in firstparity Czech Holstein cows. Czech J Anim Sci 57: 108-114

Zishiri OT, Cloete SWP, Olivier JJ, Dzama K 2014: Genetic parameters for live weight traits in South African terminal sire sheep breeds. Small Ruminant Res 116: 118-125 